\title{
Pultenaea parrisiae (Fabaceae: Mirbelieae), a new species from south-eastern Australia
}

\author{
J.D. Briggs and M.D. Crisp
}

\begin{abstract}
Briggs, J.D. ${ }^{1}$ and Crisp, M.D. ${ }^{2}\left({ }^{1}\right.$ CSIRO Division of Plant Industry, P.O. Box 1600, Canberra, ACT Australia 2601; ${ }^{2}$ Division of Botany and Zoology, Australian National University, Canberra, ACT Australia 0200). Pultenaea parrisiae (Fabaceae: Mirbelieae), a new species from south-eastern Australia. Telopea 5(4): 647-655. A new Pultenaea species, known only from the margins of a few swamps on the Central and Southern Tablelands of New South Wales and from north-east Gippsland, Victoria, is described and named. Two subspecies are recognised. The species is related to $P$. paleacea Willd. Pultenaea parrisiae subspecies parrisiae is assessed as having a Vulnerable conservation status, whilst $P$. parrisiae subspecies elusa is considered Endangered.
\end{abstract}

\section{Introduction}

The first record of this species appears to be a collection made in 1860 by Ferdinand von Mueller from the Upper Genoa River, Victoria. Subsequently it was collected four times (in 1887, 1948, 1970 and 1984) in Victoria, all in East Gippsland, and three times (twice in 1938 and once in 1971) in south-eastern New South Wales. These collections had been determined as Pultenaea paleacea Willd. var. paleacea.

Pultenaea parrisiae came to our attention in 1987 when one of us (MDC) saw a Pultenaea specimen which did not match any described species. This had been collected by amateur botanist Mrs Margaret Parris in 1972 from a swamp in Wadbilliga National Park. As this Pultenaea appeared to be both new and rare, the senior author (JDB) undertook field searches with the assistance of Mrs Parris. We relocated small populations of this inconspicuous plant and were able to confirm our initial opinion that it was a distinct species. Subsequent investigations assisted by Margaret Corrick from the National Herbarium, Melbourne, led to the discovery of the Victorian records and revealed two specimens collected from Penrose and Wingello, New South Wales, which we are recognising as a subspecies ( $P$. parrisiae subsp. elusa). Pultenaea parrisiae subsp. parrisiae has been included in Flora of New South Wales (Weston 1991:485) as 'species $\mathrm{K}^{\prime}$ and in Briggs and Leigh (1988) as 'sp. 1 (W of Wadbilliga trig.)'. In this paper we describe and name the new Pultenaea species and discuss its affinities, distribution, habitat and conservation status.

\section{Taxonomy}

Pultenaea parrisiae J.D. Briggs $\mathcal{E}$ Crisp, sp. nov.

$P$. paleaceae Willd. similis sed floribus bracteisque dimidio minoribus pedicellis praesentibus et habitu humiliore procumbenti differt.

HolotyPus: New South WALEs: Southern Tablelands: Wadbilliga National Park, 0.9 km E from the western boundary of the park on the Razorback Fire Trail, 36 $20^{\circ} 50^{\prime \prime}, 149^{\circ}$ 32' 45", J.D. Briggs 2458, 13 Nov 1988 (CBG). ISOTYPI: BRI, HO, MEL, NSW, K. 

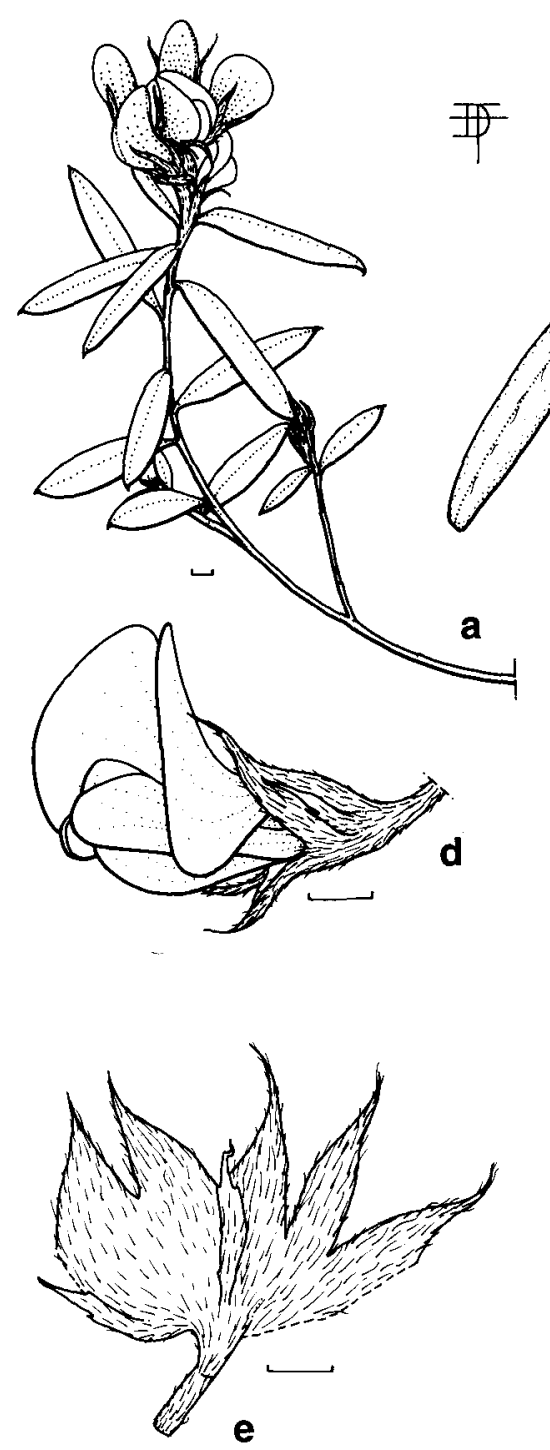

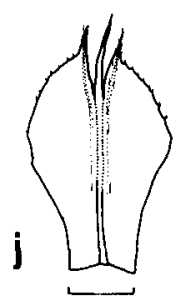

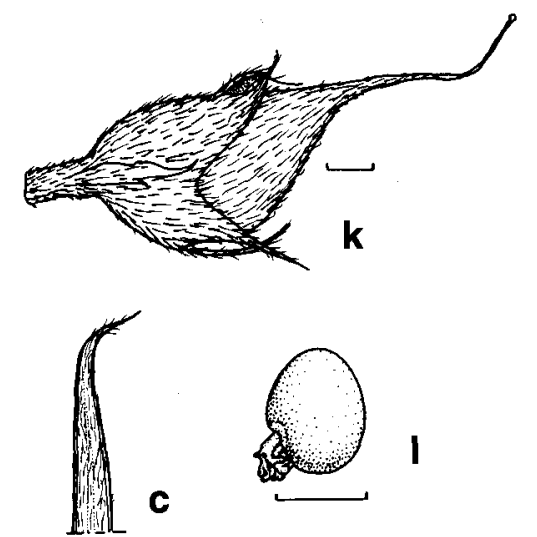

b
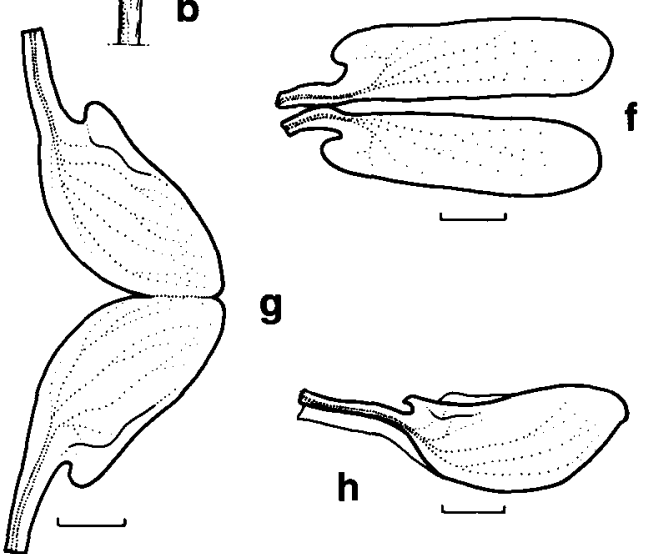

g
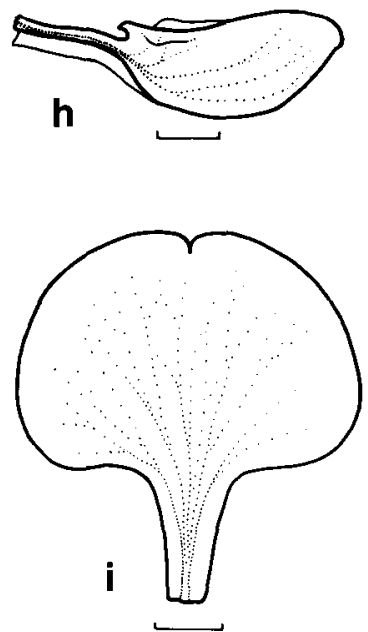

Figure 1. Pultenaea parrisiae subsp. parrisiae. $\mathbf{a}$, flowering branchlet; $\mathbf{b}$, segment of branchlet showing stipules, adaxial surface and insertion of leaf; $c$, acuminate leaf apex and abaxial leaf surface; d, flower; e, calyx; $\mathbf{f}$, wing petals; $\mathbf{g}$, h, keel petals; $\mathbf{i}$, standard petal; $\mathbf{j}$, floral bract; $\mathbf{k}$, young fruit; l, seed; a-c, k,l, from cultivated plant ex J.D. Briggs 2458; d-j, from J.D. Briggs 2458 pickled material. Scale bars are $1 \mathrm{~mm}$ long, except a $(2 \mathrm{~mm})$ and $\mathbf{l}(0.5 \mathrm{~mm})$. 
Diminutive procumbent $s u b s h r u b$ with few, slender, trailing, weakly branched stems $30-40(-60) \mathrm{cm}$ long arising from a slender rootstock; initially with a densely appressed silky pubescence but soon glabrous. Cotyledons sessile, oblong, 3.5-4 mm long, 1-1.5 mm wide, dark glossy green; lamina moderately thick, convex above, concave beneath and slightly recurved from central axis. Seedling leaves elliptic to obovate, 3-10 $\mathrm{mm}$ long, 2-6 mm wide, increasing in size as plants develop, grading to the adult form. Adult leaves alternate, sparse, minutely petiolate, linear to narrowly oblanceolate, 4-14(-17) $\mathrm{mm}$ long, $0.8-2.5(-3) \mathrm{mm}$ wide, with a brown usually strongly recurved acuminate apex; margins recurved; upper surface distinctly concave, often with a row of simple appressed hairs along inconspicuous midrib; lower surface initially silky with appressed hairs, glabrescent; stipules tightly appressed to stem, 3-7 $\mathrm{mm}$ long, about $0.5 \mathrm{~mm}$ wide, dark or very pale brown, scarious and with 2 parallel nerves each ending in an acuminate lobe. Inflorescence a small dense terminal head of 4-7 flowers; heads subtended by persistent, imbricate, reddish- to pale-brown scarious bracts; bracts ovate to elliptic, 4-9 mm long, 1.5-2 mm wide, glabrous with sparsely ciliate margins, usually with 3 parallel central nerves, the two outer each ending in an acuminate lobe $1.2-5 \mathrm{~mm}$ long; lobes separated by a glabrous or villous central linear awn as long or longer than lobes and formed by an extension of the central nerve. Flowers 5-7 mm long; pedicels $0.4-1.5 \mathrm{~mm}$ long. Bracteoles scarious, attached $0.5-1 \mathrm{~mm}$ above base of calyx, 3-3.6 mm long, narrow-elliptic, acuminate, concave, keeled, with scattered long white hairs, particularly along outer edge of keel. Calyx tube 2-2.7 mm long with acute to finely tapering acuminate lobes $1.5-3.3 \mathrm{~mm}$ long, moderately densely silky hairy, pale greenish with reddish tinge on inside base of calyx lobes. Standard 3-4 mm across, 5-6 mm high including the claw, remaining partly folded along vertical axis, inner surface yellow with faint reddish-orange ring near base, outer surface reddish orange grading to yellow on margins; wings linear with an obtuse apex, 4-5 $\mathrm{mm}$ long and $1 \mathrm{~mm}$ wide, yellow with reddish-orange line along lower edge; keel petals $4-5 \mathrm{~mm}$ long and $2.5 \mathrm{~mm}$ across, each with a claw $1 \mathrm{~mm}$ across, joined together by a small section from the tip to about $2 / 3$ the way from the base, dark reddish brown to reddish orange near tip grading abruptly to pale greenish at base. Style and stamens of equal length, slightly upwardly curved; anthers initially purple. Ovary densely silky with long white hairs; style tapering to a blunt point. Pod flattened, \pm deltoid, 4-5 $\mathrm{mm}$ long and 3-3.5 $\mathrm{mm}$ high at widest point, with obtuse base, moderately densely sericeous; style partially persistent and usually upwardly curved, initially $4-4.5 \mathrm{~mm}$ long. Seed ovoid to sub-spherical and slightly laterally flattened, $1.2-1.5 \mathrm{~mm} \times 0.9-1.2 \mathrm{~mm}$; testa shiny pale brown to occasionally black, with prominent notch and swelling at point of attachment of the aril; aril white and manifestly papillate (Figure 1).

EтумоLogr: Named after Margaret Parris, an amateur botanist who lived in Cooma for many years and now lives in Merimbula. She has made a great many valuable botanical collections (including this species) from the Southern Tablelands and South Coast regions of New South Wales.

Two subspecies are recognised (see key after discussion).

\section{Pultenaea parrisiae J.D. Briggs \& Crisp subsp. parrisiae}

Distinguished from $P$. parrisiae subsp. elusa in having relatively long, subulate calyx lobes which are as long as or longer than the tube; longer pedicels (1-1.5 mm compared with $0.4-0.5 \mathrm{~mm}$ ); reddish brown, shorter floral bracts $(4-5.5 \mathrm{~mm}$ long compared with $8-9 \mathrm{~mm}$ ), which terminate in lobes of only about $1 / 3$ their total length and have a \pm glabrous central awn.

Flowering Period: Mainly November but occasionally commencing in October. 
DISTRIBUTION: Pultenaea parrisiae subsp. parrisiae has been re-located by us at two sites ( $3 \mathrm{~km}$ apart) near the head of the Tuross River in Wadbilliga National Park on the Southern Tablelands of New South Wales and at one site near Buldah in north-east Gippsland, Victoria (Figure 2).

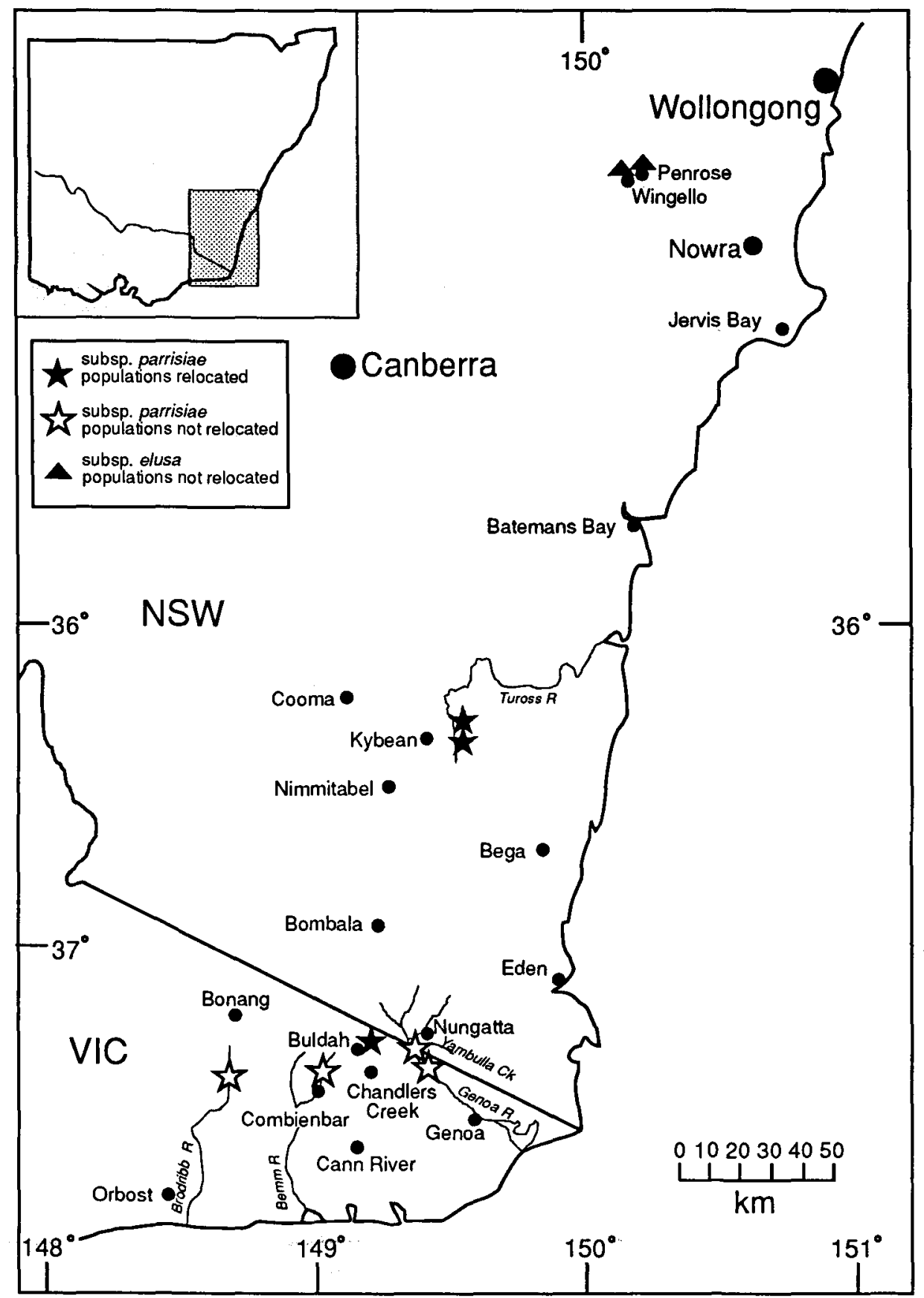

Figure 2. Distribution of Pultenaea parrisiae. 
There have been four other collections in east Gippsland, but the localities given for two of these are too vague to justify searching. Unsuccessful efforts have been made to re-locate the species at the other two sites. The Genoa River site was found to be very different from the swamp habitat of the known localities and it appears either that plants may have only temporarily established there from seed washed downstream from another locality or that an error has occurred in the labelling of the locality for that specimen. At the Bonang Highway site, suitable habitat was found but $P$. parrisiae was not seen, possibly because it was not flowering at the time.

A search at the herbaria NSW by MDC and P.H. Weston, and CANB by JDB, failed to locate any additional collections of subsp. parrisiae from New South Wales. It is, however, likely that additional populations will eventually be found in both New South Wales and Victoria as there are numerous potential sites within the recorded range of the species.

HAвітAт: Pultenaea parrisiae subsp. parrisiae occurs on grey sandy loams or clay-loams in seasonally waterlogged conditions around the margins of permanent swamps or seepage areas, mostly at altitudes ranging from 550 to $1045 \mathrm{~m}(250 \mathrm{~m}$ at the Bonang Highway site). It occurs in low, open, wet-heath and herbfield in or on the margins of eucalypt woodland. The woodland associations include Eucalyptus viminalis Labill., E. pauciflora Sieber ex Spreng., E. dalrympleana Maiden, E. consideniana Maiden and Eucalyptus radiata Sieb. ex DC. At the New South Wales localities P. parrisiae subsp. parrisiae grows with Pultenaea capitellata Sieb. ex DC. with which it can be superficially confused. Other associated species at the New South Wales sites include Banksia canei J.H. Willis, B. marginata Cav., Leptospermum myrtifolium DC., Baeckea utilis Miq., Epacris microphylla R. Br., E. paludosa R. Br., Brachyloma daphnoides Benth., Bossiaea foliosa Cunn., Gompholobium huegelii Benth., Lomandra longifolia Labill., Patersonia sp. and Poa $\mathrm{sp}$. Associated species at the Victorian site included Daviesia latifolia R. Br., Melaleuca squarrosa Smith, Leptospermum juniperinum Smith, Bossiaea prostrata R. Br., Lomandra longifolia, Comesperma ericinum DC., Poa tenera J.D. Hook., Gahnia radula (R. Br.) Benth. and Lepidosperma sp.

BIOLOGY: Glasshouse-grown plants have proved to be intolerant of moisture stress. Glasshouse plants have readily produced seed in the absence of any obvious insect pollinators, thus indicating an apomictic ability or self-pollination. Such an ability may compensate for the insignificant flowers, unusually small for the genus, which may not function as efficient attractants to pollinators. Seed produced in cultivation has germinated readily following scarification, but has also occasionally germinated in glasshouse conditions without any treatment.

Conservation Status: Pultenaea parrisiae subsp. parrisiae is listed as Vulnerable (code 2VCi) in Briggs \& Leigh (1988), as 'Pultenaea sp.1 ( $\mathrm{W}$ of Wadbilliga trig)'. The code is amended here to $3 \mathrm{VCi}$ (i.e. range now $>100 \mathrm{~km}$ ).

Searches of several swamps in the general vicinity of the type locality of subsp. parrisiae found only two populations with a total of between 800 and 1000 plants over a total area of 1.25 ha. Although these populations are within a national park the habitat type is one often severely disturbed by feral pigs. At the surveyed Victorian site an estimated 400 plants occupy an area of only 0.1 ha in State Forest.

OTHer Specimens Examined: New South Wales: Southern Tablelands: Bog, Tuross headwaters area, Wadbilliga Fire Trail, M. Parris, 21 Nov 1972 (CBG); Wadbilliga National Park, near the head of a small tributary to Back Creek, $2.7 \mathrm{~km}$ direct ESE of the junction of the Tuross River and Back Creek, J.D. Briggs 2456 \& M. Parris, 12 Nov 1988 (CBG, K, NSW, MO), J.D. Briggs 2184 \& M. Parris, 9 Jan 1987 (CANB, CBG); ex J.D. Briggs \& M. Parris 2184, seedling cultivated at CSIRO Plant Industry, Canberra, J.D. 
Briggs 2688, 4 Feb 1992 (CANB). VICTORIA: East Gippsland: Gravelly bank of the Upper Genoa River, F. Mueller s.n., Sep 1860 (MEL); Eastern head of Bemm River, Coombinbah [Combienbar] Valley, c. 25 miles [40 km] E and NE of Mt Ellery, E. Merrall s.n., Nov 1887 (MEL); Sandstone area along Yambulla Creek and Upper Genoa River, at NSW border, J.H. Willis s.n., 17 Oct 1948 (MEL); Between Dead Bull and Dead Calf Creeks, Bonang Highway, border of grids Z19-1 and Z20-2, A.C. Beauglehole 34962, 25 Nov 1970 (MEL); $5.7 \mathrm{~km}$ ENE of Buldah township, 37 $15^{\prime} 43^{\prime \prime}, 149^{\circ} 12^{\prime 2} 0^{\prime \prime}$, G.W. Carr 10097, 26 Oct 1984 (MEL, CBG); State Forest, $18.5 \mathrm{~km}$ by road and track NW and N of Chandlers Creek, $50 \mathrm{~m} \mathrm{~S}$ of Fiddlers Green Creek and $100 \mathrm{~m} \mathrm{~W}$ of Fiddlers Green Fire Trail, J.D. Briggs 2511, 23 Nov 1989 (AD, CANB, B, K, MEL, NSW), J.D. Briggs 2512 (CANB), J.D. Briggs 2513 (CANB, MEL, NSW, MO), J.D. Briggs 2514 (BRI, CANB, CBG, HO, MEL, NSW), J.D. Briggs 2514b (CANB).

Pultenaea parrisiae subsp. elusa J.D. Briggs $\mathcal{E}$ Crisp, subsp. nov.

A $P$. parrisiae subsp. parrisiae distinguenda calycis lobis tubo brevioribus, pedicellis brevioribus (0.4-0.5 mm longis), bracteis pallide fulvis longioribus (8-9 mm longis) quae ad infra medium in lobos duo arista longiore conspicue villosa divisae sunt.

Holotypus: New South Wales: Central Tablelands: Wingello in swamps, W.F. Blakely s.n., 30 Sep 1938 (NSW).

Distinguished from $P$. parrisiae subsp. parrisiae in having relatively short calyx lobes which are shorter than the tube; short pedicels $(0.4-0.5 \mathrm{~mm})$; longer and very pale brown bracts (8-9 $\mathrm{mm}$ long) which terminate in two lobes of more than half their total length and have a longer and conspicuously villous central awn.

ETYMOLOGY: From the Latin verb eludo, to avoid, evade or frustrate, referring to our lack of success in re-locating populations.

Flowering Period: Specimens indicate late September and October.

Distribution: Known only from two specimens collected in 1938 from Penrose and Wingello, 30-40 km south-west of Mittagong in the south-east of the New South Wales Central Tablelands. These localities are $190 \mathrm{~km}$ north of the nearest known populations of $P$. parrisiae subsp. parrisiae.

HABrTAT: 'In swamps' is the only information recorded. The altitudes of swamps in this area are around $600 \mathrm{~m}$.

Conservation Status: We recommend that $P$. parrisiae subsp. elusa be considered Endangered (code 2E according to the criteria of Briggs \& Leigh, 1988).

Despite two separate full day searches of many swamp habitats in the vicinity of, and between, the two recorded localities subsp. elusa could not be re-located by the authors. Many of the numerous swamps in the area occur on private property, although there are some in State Forest or on Crown Land. Most of those on private property have been adversely affected by grazing by domestic stock and associated farming activities, whilst those in State Forest and on Crown Land were generally in a relatively unmodified natural condition. Further searches are warranted in the latter, particularly in mid to late September. The lack of precise localities on Blakely's original specimens adds to the difficulty of searching for this inconspicuous taxon. Efforts to obtain additional information about Blakely's collection sites have been unsuccessful.

Other Specimen Examined: New South Wales: Central Tablelands: Penrose, in swamps, W.F. Blakely \& W. Buckingham s.n., Oct 1938 (NSW).

Discussion: Table 1 compares diagnostic characters in both subspecies of $P$. parrisiae and the varieties of $P$. paleacea. 
Table 1. Comparison of selected characters for Pultenaea parrisiae and the described varieties of $P$. paleacea.

Pultenaea parrisiae Pultenaea parrisiae P. paleacea

subsp. parrisiae subsp. elusa var. paleacea

P. paleacea

P. paleacea

P. paleacea

P. paleacea

var. sericea var. pauciflora

var. williamsonii

var. robusta

Habit

Subshrub with weak Subshrub with

Spreading shrub Subshrub with Shrub to $1 \mathrm{~m}$

Shrub with flat

Shrub to $1 \mathrm{~m}$

rootstock and slender stems to

or subshrub

stout rootstock

high with

leaves

high with woody

straggling stems
to $60 \mathrm{~cm}$ long

$50 \mathrm{~cm}$ long

and stems to

densely

crowded \pm

flat leaves

Leaf length (mm)

$4-17$

5-16

9-23

6-19

5-15

$7-23$

rootstock

Leaf width (mm)

$0.8-3$

0.6-2

$0.8-5$

$[10-30]^{10}$

Stipule length (mm)

3-7

5-9

1-2.5

$$
1-3
$$

4-5

2-7

$5-10[3-11]$

6-10

$$
\text { 5-7 }
$$

(10)20-40

\begin{tabular}{|c|c|c|}
\hline $\begin{array}{l}\text { No. of flowers/ } \\
\text { inflorescence }\end{array}$ & $4-7$ & $5-7$ \\
\hline Pedicel length (mm) & $1-1.5$ & $0.4-0.5$ \\
\hline $\begin{array}{l}\text { Standard } \\
\text { length }(\mathbf{m m})\end{array}$ & $5-6$ & $6-7$ \\
\hline Calyx tube length (mm) & $2-2.5$ & $2.2-2.7$ \\
\hline Calyx lobe length (mm) & $2.5-3.3$ & $1.2-1.5$ \\
\hline $\begin{array}{l}\text { Bracteole } \\
\text { attachment from } \\
\text { base of calyx (mm) }\end{array}$ & $0.5-1$ & $0.5-1$ \\
\hline Bracteole length (mm) & $3-3.6$ & 3 \\
\hline $\begin{array}{l}\text { Length of longest } \\
\text { floral bracts }(\mathrm{mm})\end{array}$ & $4-5.5$ & $8-9$ \\
\hline $\begin{array}{l}\text { Floral bract } \\
\text { and stipule colour }\end{array}$ & $\begin{array}{l}\text { Reddish } \\
\text { brown }\end{array}$ & $\begin{array}{l}\text { Very pale } \\
\text { brown }\end{array}$ \\
\hline $\begin{array}{l}\text { Calyx hair } \\
\text { colour }\end{array}$ & White & $\begin{array}{l}\text { Pale } \\
\text { golden }\end{array}$ \\
\hline
\end{tabular}

$[4]^{1,4}$

4-8(10)

\author{
10-14
}

$1-3$

10-15

7-10

sessile

sessile

10-12

$[6-10]^{5}$

$[7-11]^{6}$

4-5

8-10

$0(-0.5)$

9-11

$0(-0.5)$

10-11

sessile

9-10

$3.5-4$

3.5-4

2-2.5

$1.5-2$

4-5.5

4.5-6

2-3

\title{
2-3
}

1.5-2.5

4-5

5-11

7.5-11.5

$$
[8-10]^{3}
$$

Dark reddish

brown

Pale straw

brown

White (rarely

Pale golden

1.5-2

4.5-5

5-6

1.3-1.8

2.5-3

pale golden

Brown to

dark brown

0.5

$2-2.5$

4.5-5

4-6

$5-7$

$10-12$

brown)

Dark reddish Reddish

brown brown

Golden \pm White

Note. Values in brackets [ ] indicate those given in literature which differ from the range measured by the authors. The superscript number refers to the relevant reference as numbered in this paper. 
Pultenaea parrisiae is most closely related to $P$. paleacea Willd. var. paleacea with which it has in common: conspicuous, persistent, predominantly glabrous, imbricate floral bracts surrounding relatively small (for the genus) dense, terminal 4-8 flowered inflorescences, and slender, linear leaves which have recurved margins, recurved acuminate tips and silky hairy undersurfaces. Subsp. parrisiae also shares the features of dark reddish brown floral bracts and stipules, and appressed silky white hairs on the calyx. Pultenaea parrisiae is readily distinguished from $P$. paleacea var. paleacea in consistently having pedicellate flowers which are only about half the size, and a more diminutive procumbent habit including generally shorter leaves and stipules. P. parrisiae subsp. parrisiae is further distinguished from $P$. paleacea var. paleacea in having relatively longer subulate calyx lobes divided to, or slightly more than, half the length of the calyx. These characteristics of $P$. parrisiae subsp. parrisiae have been maintained in glasshouse-grown specimens, indicating that they are genetically fixed. On herbarium material the calyx tips of $P$. parrisiae subsp. parrisiae are clearly visible beyond the bracts, whereas for $P$. paleacea var. paleacea the calyces are entirely obscured. Pultenaea paleacea var. paleacea occurs generally as an understorey shrub or subshrub in coastal woodland and open-forest communities from Jervis Bay to north of Port Stephens and is thus geographically and ecologically well separated from $P$. parrisiae. The latter is a swamp-dwelling species of tablelands and mountainous terrain, generally at altitudes above $550 \mathrm{~m}$.

We have concluded that the combination of the shared characteristics of swamp habitat, diminutive growth habit and small, pedicellate flowers suggest a close ecological and phylogenetic relationship between the two entities within P. parrisiae and these serve to readily distinguish them from their nearest relatives. Most of the differences between the two subspecies of $P$. parrisiae are quantitative characters such as pedicel length and stipule length such as might be expected between geographically disjunct populations within a species (see Table 1). The relatively short calyx lobes in $P$. parrisiae subsp. elusa suggests a link between this entity and $P$. paleacea var. paleacea but this may be plesiomorphic similarity. On the other hand, the pale floral bracts and stipules and pale golden calyx hairs of $P$. parrisiae subsp. elusa resemble those of $P$. paleacea var. sericea. This may be convergence because the latter is otherwise very different. We have opted for subspecific ranking of elusa because it shares with $P$. parrisiae subsp. parrisiae the unique characters (within the group) mentioned above, thus suggesting that these taxa comprise a monophyletic group. Neither taxon has unique, qualitative characters that might support their separate recognition as species.

Several other varieties of $P$. paleacea have been described, i.e. var. sericea Benth., var. pauciflora C. White, var. robusta H.Williamson and var. williamsonii (Maiden) H.Williamson. Examination of herbarium specimens has led us to share the view of White (1939) that many (perhaps all) of these varieties should be raised to specific status. However, to do so formally would be beyond the scope of this paper. These other varieties all differ further from $P$. parrisiae than does $P$. paleacea var. paleacea (see Table 1).

The key for New South Wales species of Pultenaea by Weston (1991: 481) should be amended as follows:

\section{$10^{*}$ Longest leaves $12-23 \mathrm{~mm}$ long}

11 Flowers 10-12 mm long, sessile; longest leaves to $23 \mathrm{~mm}$; bracteoles 4-6 mm long; small spreading shrub or subshrub 5 P. paleacea

11*Flowers 5-7 mm long, pedicellate; longest leaves to $17 \mathrm{~mm}$; bracteoles 3-3.6 mm long; diminutive procumbent subshrub 7 P. parrisiae (sp.K) 
Calyx lobes accuminate and as long or longer than the tube; floral bracts and stipules dark reddish brown 7a P. parrisiae subsp. parrisiae

Calyx lobes much shorter than the tube; floral bracts and stipules very pale brown $7 \mathrm{~b}$ P. parissiae subsp. elusa

Note: The illustrations for $P$. paleacea and $P$. sp. $K$ in the above publication should be interchanged.

In the key for Victorian Pultenaea presented by Willis (1972: 262) P. parrisiae can be similarly distinguished from $P$. paleacea by applying the same criteria as that suggested for couplet 11 in Weston (1991).

\section{Acknowledgements}

The authors thank Margaret Parris for her assistance in the field in locating the site of her original New South Wales collection. Mr W. McCallum is also thanked for assisting whilst attempting to relocate the Yambulla Creek site. We are grateful to our colleagues Margaret Corrick at MEL and Peter Weston at NSW for searching for collections of $P$. parrisiae at their institutions and to the directors of those institutions in facilitating loans of relevant specimens. Donald Fortescue is thanked for the line drawing of the new species.

\section{References}

1. Bentham, G. (1864) Flora Australiensis, vol. 2:115-116 (Lovell Reeve and Company: London).

2. Briggs, J.D. \& Leigh, J.H. (1988) Rare or Threatened Australian Plants: 1988 revised edition, 278 pp. Special Publication 14 (Aust. Natl. Parks and Wildlife Service: Canberra).

3. Curtis, W.M. \& Morris, D.I. (1975) The Students Flora of Tasmania, edn 2, part I:140.

4. Ewart, A.J. (1930) Flora of Victoria: 628 (Govt. Printer: Melbourne).

5. Thompson, J. (1961) Contr. New South Wales Natl Herb. Fl. Ser. 101(1):52-53.

6. Weston, P.H. (1991) Pultenaea, in Harden, G.J. (ed.) Flora of New South Wales, vol. 2:485. (Univ. New South Wales Press: Sydney).

7. White, C.T. (1939) Contributions to the Queensland Flora, No. 6. Proc. Roy. Soc. Queensland 50: 66-87.

8. Willdenow, C.L. von (1799) Species Plantarum edn 4, 2(1).

9. Williamson, H.B. (1920) A revision of the genus Pultenaea, Part 1. Proc. Roy. Soc. Victoria ser. 2, 32(2): 210-224.

10. Willis, J.H. (1972) A Handbook of Plants in Victoria, vol. 2:262-263 (Melbourne University Press: Melbourne). 